\title{
Changes of hematological characteristics of greenling (Hexagrammos otakii Jordan and Starks) by anaesthetics
}

\author{
I.-S. Park ${ }^{1 *}$, H. W. Gil ${ }^{1}$ and J. W. Hur ${ }^{2}$ \\ ${ }^{1}$ Division of Marine Bioscience, Korea Maritime and Ocean University, Busan 606-791, Korea \\ ${ }^{2}$ Bio-Monitoring Center, Daejeon 302-834, Korea
}

\begin{abstract}
Blood (hematocrit, hemoglobin and red blood cell) and plasma (cortisol, glucose, lactic acid, $\mathrm{Na}^{+}, \mathrm{Cl}^{-}, \mathrm{K}^{+}$, osmolality, aspartate aminotransferase and alanine aminotransferase) factors in greenling, Hexagrammos otakii after MS-222 and lidocaine- $\mathrm{HCl}$ anaesthetic were determined. Greenling (mean body length: $25.8 \pm 1.6$ $\mathrm{cm}$, mean body weight: $194.5 \pm 33.8 \mathrm{~g}$ ) were exposed to concentrations of $125 \mathrm{ppm} \mathrm{MS}-222$ and $800 \mathrm{ppm}$ lidocaine- $\mathrm{HCl}$ at $18^{\circ} \mathrm{C}$. Blood was collected from ten fish after anesthesia $0.5,1,3,6$ and 24 hours, respectively. After anesthesia, the concentrations of hematocrit, hemoglobin, red blood cell, cortisol, glucose, lactic acid, osmolality, $\mathrm{Na}^{+}, \mathrm{K}^{+}, \mathrm{Cl}^{-}$, aspartate aminotransferase and alanine aminotransferase were determined. Control and experimental group displayed significant increases in plasma cortisol concentrations from their respective prestress levels at 0.5 hour after anaesthetic $(P<0.05)$. Concentrations of glucose were increased from 22.3 ng/ $\mathrm{mL}$ to $28.5 \mathrm{ng} / \mathrm{mL}$ ( 0.5 hour), $31.0 \mathrm{ng} / \mathrm{mL}$ (1 hour) in experimental group, respectively. Lactic acid concentrations for experimental group were lower than those for control group at $0.5,1$ and 3 hours. In other items, control and experimental group did not show significant differences in this before and after anaesthetic. The results indicate that lidocaine- $\mathrm{HCl}$ and MS-222 can be used as suitable anaesthetic for the greenling.
\end{abstract}

\section{Introduction}

Farmed fish can be subjected to a range of stresses including handling, confinement, transport, medication, water quality, and changes in water temperature and salinity [1]. Anesthesia is primarily used to immobilize animals to facilitate the handling process without time waste and stress on animals [2]. Among its principal uses, anesthesia facilitates the operations: to weigh and measure; mark and tag; study fish physiology and behavior; perform surgery; collect fish in tidal pools and with scuba; photography; manually spawn; inject vaccines and antibiotics; and collect blood and other tissues [1]. In addition, anesthesia proved to be an effective method for the transport of the fish as sedation [1-3].

Considering toxicity (safety to users and to fish), efficacy, price, regulations when used and the purpose of using anesthesia, ideal anesthesia is needed. This ideal anesthesia should meet following characteristics: (1) anesthesia time within $3 \mathrm{~min}$ and recovery time within $5 \mathrm{~min}$; (2) non-toxic to the fish; (3) ease of use and non-toxic to the user; (4) non-effective to the physiology and the movement of the experimented fish; (5) anesthesia should be excreted from internal body so that requires no withdrawal period; (6) no accumulation effect by repetition of anesthesia and no side-effect; and (7) cost-effectiveness [3].

Traditionally, chemicals such as urethane, ether and chloroform were used to anesthetize fish; however, these substances are now restricted because they all contain carcinogens [4]. Currently, tricaine methanesulfonate (MS-222) is widely used to anesthetize fish, including food fish, although it is considered mildly toxic as an edible anesthetic according to the US Food and Drug Administration (FDA), which requires that fish treated with MS-222 undergo an obligatory 21-days withdrawal period [2].
Human anesthetic compound lidocaine-HCl [2-(diethylamino)$\mathrm{N}$-(2, 6-dimethylphenyl) acetimide hydrochloride] is a white powder soluble in water, and was first administered to fish by previous study [5]. A more effective and risk-free anesthetic, such as lidocaine- $\mathrm{HCl}$, which has been safely used in the dentistry industry, has been proven as a safe substitute for application on some freshwater and marine fishes in Korea [1,6]. A number of studies have investigated its effectiveness, economic viability, reusability, toxicity and side-effects to ascertain its appropriateness as a fish anesthetic [2].

The greenling, Hexagrammos otakii (Jordan and Starks) is commonly found in coastal areas of Korea throughout the year [7]. The greenling is a number of the typical seawater Hexagrammidae and a commercially important greenling species, and this species is a favorite seawater food fish because of its taste and tender meat [7]. Previous study reported the anesthesia effects of MS-222 and lidocaine- $\mathrm{HCl}$ on the greenling [3]. Park et al. (2003) suggested that both anesthetics were effective chemicals for the transport of the greenling as sedation [3]. However, no study has investigated possible physiological stresses and hematological characteristics of this species by anesthesia. The aim of this study was to establish physiological stresses and hematological characteristics of the greenling in optimum concentration of MS-222

Correspondence to: I-S Park, Division of Marine Bioscience, Korea Maritime and Ocean University, Busan 606-791, Korea, Tel: +82 51410 4321; Fax: +82 51 404 4750; E-mail: ispark@kmou.ac.kr

Key words: greeenling, hematological characteristics, Hexagrammos otakii, MS 222, lidocaine- $\mathrm{HCl}$

Received: August 12, 2015; Accepted: September 14, 2015; Published: September 18, 2015 
and lidocaine-HCl.

\section{Materials and methods}

The greenling, Hexagrammos otakii was reared in a recirculating culture system in the Fishery Genetics and Breeding Sciences Laboratory of Korea Maritime and Ocean University, Korea. The recirculating culture system consisted of five 1,100-L circular tanks, one 1,100-L filtering tank, an aeration system and a temperature control system. Culture water was partially replaced with sand-filtered, aerated seawater (temperature $18.3 \pm 1.4^{\circ} \mathrm{C}$, salinity $34 \pm 0.6 \mathrm{ppt}, \mathrm{pH} 7.6$ \pm 0.5 , dissolved oxygen $8.5 \pm 0.7 \mathrm{mgL}^{-1}$, ammonia $0.006 \mathrm{mgL}^{-1}$ ) every weekend. Selected samples were starved for 24 hours before the start of experiments. Specimens used in experiments were measured using a digital vernier caliper (CD-20CP, Japan) and an electronic balance (JW-1, Korea). Average body length and body weight of greenling were found to be $25.8 \pm 1.6 \mathrm{~cm}$ and $194.5 \pm 33.8 \mathrm{~g}$, respectively.

Considering the ideal anesthesia should meet characteristic of anesthesia time within $3 \mathrm{~min}$ and recovery time within $5 \mathrm{~min}$, optimum anesthetic concentration of MS-222 (Sigma, USA) and lidocaine- $\mathrm{HCl}$ (Hong Sung Chemical, Korea) with $1,000 \mathrm{ppm} \mathrm{NaHCO}_{3}$ determined $125 \mathrm{ppm}$ (MS-222) and $800 \mathrm{ppm}$ lidocaine- $\mathrm{HCl} / 1,000 \mathrm{ppm}$ $\mathrm{NaHCO}_{3}$, respectively depending on result of previous study (Tables 1 and 2) [4]. Anesthesia criterion was determined from the time when fish were stocked in anesthetized water to the time of stage A6 state, in which fish were perfectly sedate with minimum opercular movements $[4,8]$. Recovery criterion was determined from the time when the fish were stocked in recovery water to the time of the stage R6 state, in which normal swimming and responsiveness to visual stimulation was recommenced $[4,8]$.

Blood physiological response was measured according to set time intervals after anesthesia of each sample. Blood samples were extracted from ten randomly selected fish at $0,0.5,1,3,6$, and 24 hours post anesthesia. Control group was measured according to extracted time intervals of experimental group without anesthesia. Blood was collected $5 \mathrm{~mL}$ from the caudal vasculature using a disposable syringe (5 mL, Sung Shim Medical Co., Ltd, Bucheon, Korea) with heparin sodium (Shin Poong Pharm Co., Ltd, Ansan, Korea), and blood sample was extracted within $1 \mathrm{~min}$ to minimize handling stress. $2 \mathrm{~mL}$ of blood sample was analyzed hematocrit $(\mathrm{Ht})$, hemoglobin $(\mathrm{Hb})$, red blood

Table 1: Exposure and recovery time for greenling, Hexagrammos otakii anaesthetized with lidocaine- $\mathrm{HCl} / \mathrm{NaHCO}_{3}$ at $12^{\circ} \mathrm{C}, 18^{\circ} \mathrm{C}$ and $24^{\circ} \mathrm{C}^{*}$.

\begin{tabular}{|c|c|c|c|c|c|c|}
\hline \multirow{2}{*}{$\begin{array}{l}\text { Dose } \\
\left(\mathrm{mgL}^{-1}\right)\end{array}$} & \multicolumn{2}{|c|}{12} & \multicolumn{2}{|c|}{18} & \multicolumn{2}{|c|}{24} \\
\hline & ET & RT & ET & RT & ET & RT \\
\hline 100 & - & - & $215 \pm 29^{a}$ & $100 \pm 8^{a}$ & $128 \pm 15^{\mathrm{a}}$ & $86 \pm 7$ \\
\hline 200 & - & - & $163 \pm 21$ & $142 \pm 10^{b}$ & $78 \pm 6$ & $149 \pm 10^{b}$ \\
\hline 300 & $304 \pm 53$ & $46 \pm 3$ & $122 \pm 15^{b}$ & $172 \pm 12$ & $66 \pm 4$ & $208 \pm 16$ \\
\hline 400 & $294 \pm 50$ & $78 \pm 6$ & $116 \pm 10$ & $210 \pm 15^{\mathrm{c}}$ & $52 \pm 5$ & $238 \pm 15$ \\
\hline 500 & $278 \pm 41$ & $84 \pm 7$ & $112 \pm 11$ & $217 \pm 14^{\mathrm{d}}$ & - & - \\
\hline 600 & $254 \pm 35$ & $98 \pm 9^{a}$ & $94 \pm 8$ & $230 \pm 16$ & - & - \\
\hline 700 & $242 \pm 34$ & $115 \pm 9$ & $78 \pm 7$ & $232 \pm 15$ & - & - \\
\hline 800 & $219 \pm 24^{a}$ & $149 \pm 12^{b}$ & $62 \pm 4$ & $237 \pm 17$ & - & - \\
\hline 900 & $183 \pm 20$ & $200 \pm 15$ & $49 \pm 3$ & $240 \pm 20$ & - & - \\
\hline 1,000 & $179 \pm 15$ & $215 \pm 17$ & - & - & - & - \\
\hline 1,100 & $175 \pm 11$ & $217 \pm 20^{d}$ & - & - & - & - \\
\hline 1,200 & $172 \pm 10$ & $222 \pm 19$ & - & - & - & - \\
\hline
\end{tabular}

*After Park et al. (2003)[3]. ET: Exposure time (sec); RT: Recovery time (sec). Values are means \pm SD $(n=10)$ of triplicate experiment. Same superscripts are significantly different $(P<0.05)$.
Table 2: Exposure and recovery time for greenling, Hexagrammos otakii anaesthetized with MS-222 at $18^{\circ} \mathrm{C}^{*}$.

\begin{tabular}{|c|c|c|}
\hline Dose (ppm) & ET & RT \\
\hline 50 & $123 \pm 15$ & $70 \pm 6$ \\
\hline 75 & $98 \pm 9$ & $74 \pm 7$ \\
\hline 100 & $79 \pm 8$ & $82 \pm 8$ \\
\hline 125 & $58 \pm 6$ & $103 \pm 8$ \\
\hline 150 & $56 \pm 5$ & $112 \pm 10$ \\
\hline 175 & $49 \pm 5$ & $134 \pm 9$ \\
\hline 200 & $47 \pm 3$ & $144 \pm 20$ \\
\hline
\end{tabular}

*After Park et al. (2003)[3]. ET: Exposure time (sec); RT: Recovery time (sec). Values are means $\pm \operatorname{SD}(n=20)$ of triplicate experiment.

cell (RBC), osmolality, aspartate aminotransferase (AST) and alanine aminotransferase (ALT), and was determined by an auto-haematology analyzer (Sysmex XE-2100D, Sysmex Corporation, Japan). $3 \mathrm{~mL}$ of blood sample was allowed to sit for $10 \mathrm{~min}$ at room temperature prior to centrifugation (Centrifuge Micro 17R, Hanil Science Industrial Co., Ltd, Incheon, Korea) for $5 \mathrm{~min}$ at 5,600 g. The collected plasma was transferred to another $1.5 \mathrm{~mL}$ microtube and kept at $-80^{\circ} \mathrm{C}$ in a super low temperature refrigerator (CLN-50UW Nihon Freezer, Nihon Co., Japan) prior to analysis.

Plasma cortisol concentration was measured using 1470 WIZARD Automatic Gamma Counter (Cobra, Packard Co., Ramsey, MN, USA) after the antigen antibody response was derived using Coat-A-count TKCO Cortisol RIA Kit (DPC, Los Angeles, CA, USA) according to the methodology of Donaldson (1981) [9]. Lactic acid, $\mathrm{Na}^{+}, \mathrm{Cl}^{-}, \mathrm{K}^{+}$, and glucose concentration was analyzed according to methodology of Raabo and Terkildsen (1960; Kit 510, Sigma, St Louis, MO, USA) [10], where production of $\mathrm{H}_{2} \mathrm{O}_{2}$ by glucose oxidase in the presence of $o$-dianisidine was evaluated as an absorbance increase at $450 \mathrm{~nm}$. Using the SPSS statistics package (SPSS 9.0, SPSS Inc., Chicago, IL, USA), oneand two-way analysis of variance (ANOVA) were carried out to test for statistical significance $(P<0.05)$ between clove oil concentrations. Multiple comparisons were performed using Duncan's multiple range test [11]. All experiments were performed triplicate.

\section{Results and discussion}

During experiment, no fish were died due to the stress of anesthesia and syringe injection. Cortisol concentrations of the greenling, Hexagrammos otakii were increased significantly at 0.5 and 1 hour post anesthesia in control and anesthetic groups (Figure 1a). Cortisol concentrations of control group were increased from $5.9 \pm 1.4 \mathrm{ng} / \mathrm{mL}$ at 0 hour post anesthesia to $236.5 \pm 54.3 \mathrm{ng} / \mathrm{mL}$ at 1 hour post anesthesia $(P<0.05)$. Cortisol concentrations of MS-222 anesthetic group were increased from $5.3 \pm 0.8 \mathrm{ng} / \mathrm{mL}$ at 0 hour post anesthesia to $243.6 \pm 28.2$ $\mathrm{ng} / \mathrm{mL}$ at 1 hour post anesthesia, and those of lidocaine- $\mathrm{HCl}$ anesthetic group were increased from $6.4 \pm 0.6 \mathrm{ng} / \mathrm{mL}$ at 0 hour post anesthesia to $74.0 \pm 45.3 \mathrm{ng} / \mathrm{mL}$ at 1 hour post anesthesia $(P<0.05)$. After 3 hours post anesthesia, cortisol concentrations of all experimental groups didn't show significant differences between 0 hour post anesthesia and each measurement time $(P>0.05)$.

As shown in Figure 1b, the trend of glucose concentrations in all experimental groups was similar to those of cortisol concentration in all experimental groups. Compared to glucose concentration at 0 hour post anesthesia in all experimental groups, glucose concentrations from 0.5 hour post anesthesia to 3 hours post anesthesia were increased in all experimental groups. In all experimental groups, glucose concentrations at 24 hours post anesthesia were restored to those at 0 hour post anesthesia. Lactic acid concentrations of anesthetic 

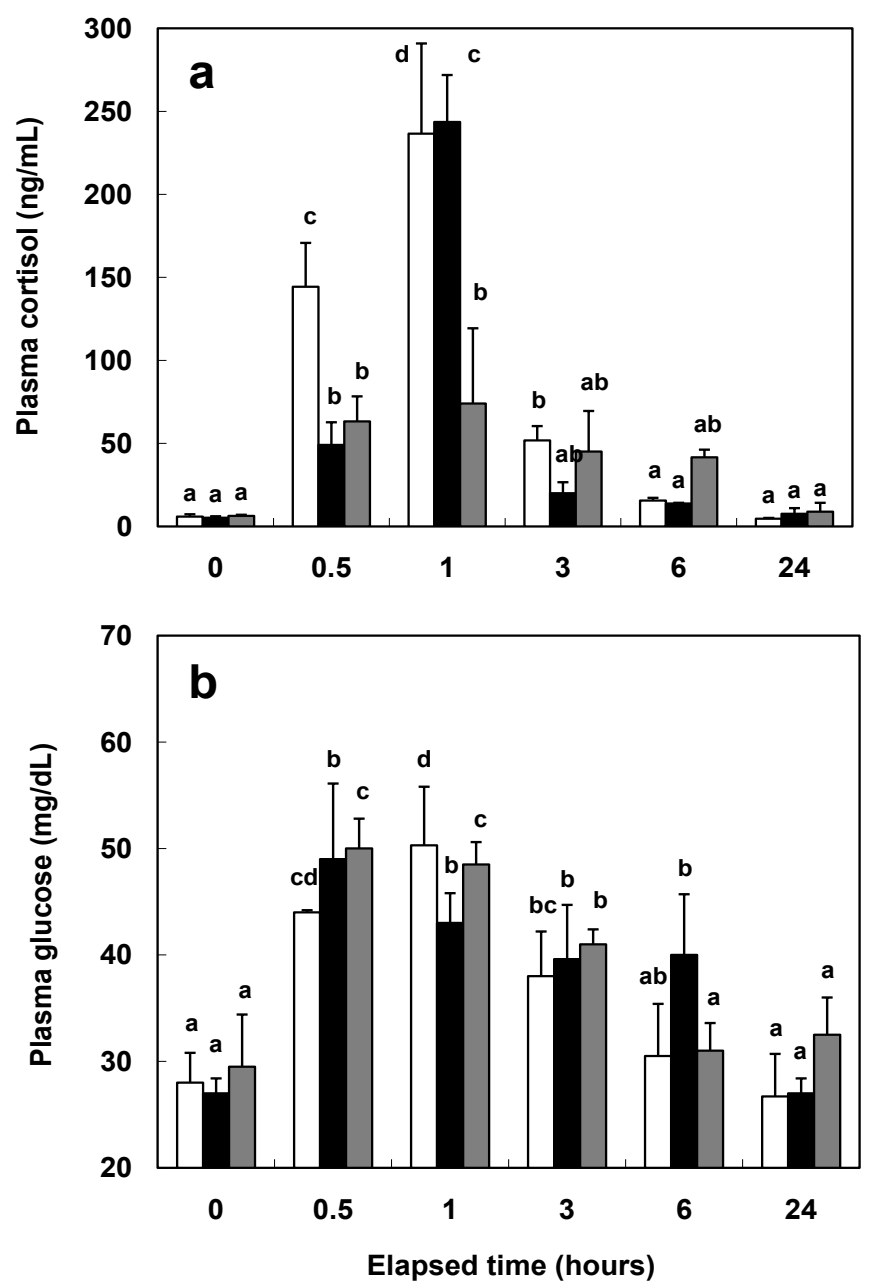

\begin{tabular}{|ll|}
\hline Control $\quad \square$ MS-222 $\quad$ Lidocaine-HCI \\
\hline
\end{tabular}

Figure 1: Change of plasma cortisol (a) and glucose (b) in greenling, Hexagrammos otakii after MS-222 and lidocaine- $\mathrm{HCl}$ anaesthetic while 24 hours. Control group was measured according to extracted time intervals of experimental group without anesthesia. The values are mean $\pm \mathrm{SD}(n=10)$ of triplicate experiments. The same alphabetic letters on the bars are not significantly different $(P>0.05)$.

groups didn't show significant differences during experimental period $(P>0.05$, Figure 2a). However, lactic acid concentrations of control group were increased significantly from $2.0 \pm 0.2 \mathrm{mmol} / \mathrm{L}$ at 0 hour post anesthesia to $3.6 \pm 0.3 \mathrm{mmol} / \mathrm{L}, 4.0 \pm 0.3 \mathrm{mmol} / \mathrm{L}$, and $3.4 \pm 0.2$ $\mathrm{mmol} / \mathrm{L}$ at $0.5,1$, and 3 hours post anesthesia $(P<0.05$, Figure $2 \mathrm{a})$. Osmolality values of control and lidocaine- $\mathrm{HCl}$ anesthetic group were no significant differences during experimental period $(P>0.05$, Figure $2 \mathrm{~b})$. But osmolality values of MS-222 anesthetic group increased to $370.3 \pm 20.7 \mathrm{mOsmol} / \mathrm{kg}$ and $359.1 \pm 5.48 \mathrm{mOsmol} / \mathrm{kg}$ at 0.5 and 1 hour post anesthesia.

In this study, greenling was shown to be sensitive to anesthetic effect of MS-222 and lidocaine- $\mathrm{HCl}$ by investigate physiological responses of MS-222 and lidocaine-HCl. Similar researches were reported for kelp grouper, Epinephelus bruneus, dark-banded rockfish, Sebastes inermis, black rockfish, S. schlegeli and rock bream, Oplegnathus fasciatus [1,1214]. As mentioned previous research, experiment without anesthesia is very stressful to fish, causing abnormal metabolic rates, oxygen consumption, blood pressure, and blood physiological responses. Moreover, these side-effects can last for hours after fish recover from shock [2]. But optimum anesthetic concentration can minimize negative impacts and thus reduce stress in fish.

Plasma cortisol and plasma glucose are recognized as useful indicators of stress in fish $[13,15]$. Plasma cortisol and glucose levels in red drum, Sciaenops ocellatus, simultaneously exposed to MS-222 and quinaldine anesthetic, were reported to be elevated [16]. Previous study stated that "Usually, phenomenon that plasma cortisol concentration of fishes rises by stress is first order reaction, phenomenon that plasma glucose concentration rises is result of second-order first order reaction by hormone rise reaction by stress" [17]. This trend has been reported in the gray mullet, Mugil cephalus and kelp grouper $[13,18]$. The results
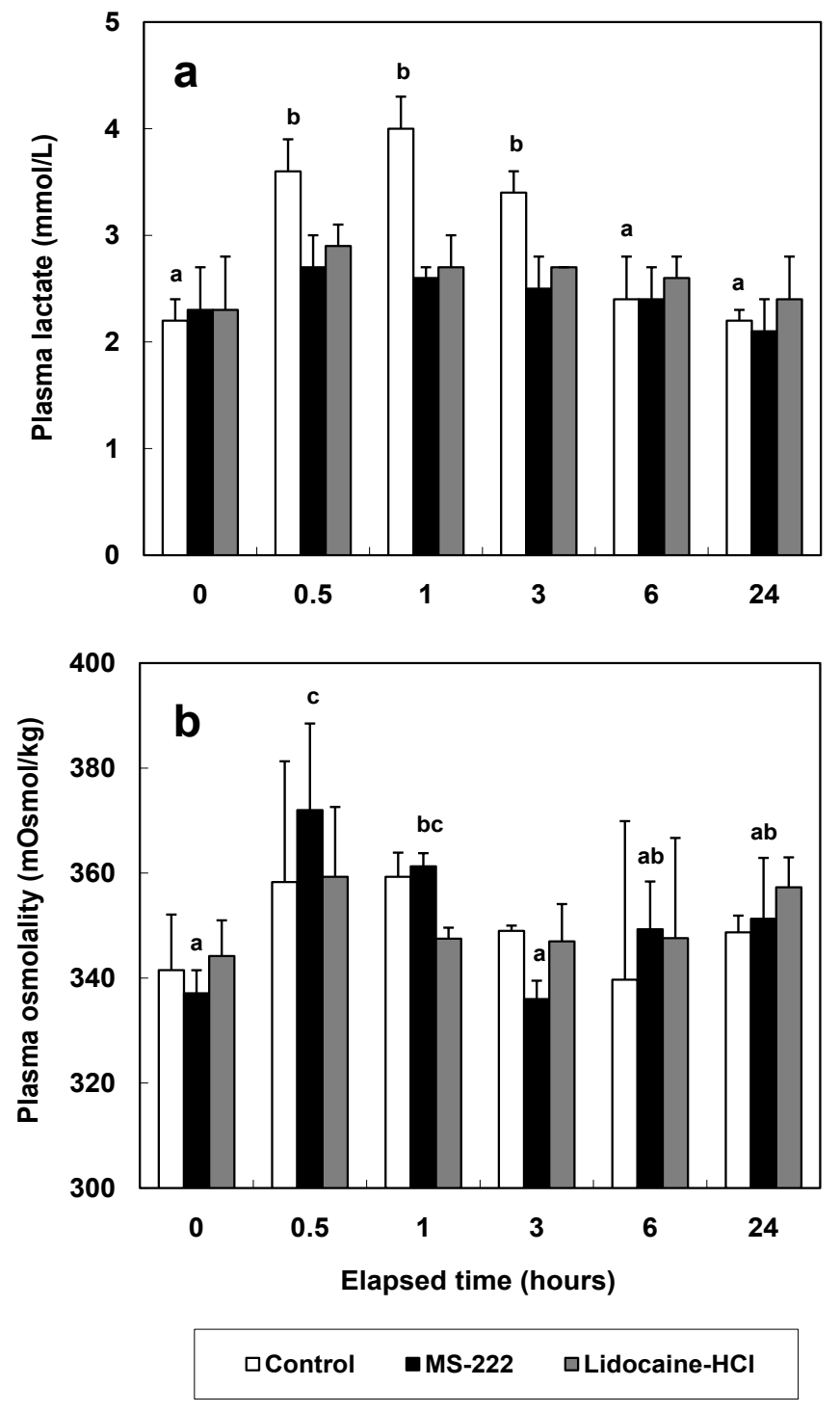

Figure 2: Change of plasma lactic acid (a) and osmolality (b) in greenling, Hexagrammos otakii after MS-222 and lidocaine-HCl anaesthetic while 24 hours. Control group was measured according to extracted time intervals of experimental group without anesthesia. The values are mean $\pm \mathrm{SD}(n=10)$ of triplicate experiments. The same alphabetic letters on the bars are not significantly different $(P>0.05)$. 
Park IS (2015) Changes of hematological characteristics of greenling (Hexagrammos otakii Jordan and Starks) by anaesthetics

Table 3: Comparison of blood and plasma factors in greenling, Hexagrammos otakii after MS-222 and lidocaine-HCl anaesthetic*.

\begin{tabular}{|c|c|c|c|c|}
\hline \multirow{2}{*}{ Items } & \multirow{2}{*}{$\begin{array}{l}\text { Elapsed time } \\
\text { (hours) }\end{array}$} & \multicolumn{3}{|c|}{ Exp.groups } \\
\hline & & Control & MS-222 & Lidocaine-HCl \\
\hline \multirow{6}{*}{$\begin{array}{l}\text { Hematocrit } \\
(\%)\end{array}$} & 0 & $24.4 \pm 4.9^{\mathrm{a}}$ & $24.3 \pm 5.9^{\mathrm{a}}$ & $25.4 \pm 4.1^{\mathrm{ab}}$ \\
\hline & 0.5 & $32.5 \pm 3.2^{\mathrm{ab}}$ & $41.8 \pm 8.6^{\mathrm{b}}$ & $24.1 \pm 7.2^{\mathrm{a}}$ \\
\hline & 1 & $38.9 \pm 7.4^{\mathrm{b}}$ & $40.0 \pm 6.5^{\mathrm{ab}}$ & $43.2 \pm 5.5^{\mathrm{c}}$ \\
\hline & 3 & $31.0 \pm 5.6^{\mathrm{ab}}$ & $28.6 \pm 9.0^{\mathrm{ab}}$ & $38.4 \pm 6.4^{\mathrm{bc}}$ \\
\hline & 6 & $31.8 \pm 7.4^{\mathrm{ab}}$ & $35.3 \pm 7.2^{\mathrm{ab}}$ & $40.7 \pm 9.7^{\mathrm{c}}$ \\
\hline & 24 & $25.8 \pm 3.0^{\mathrm{a}}$ & $29.1 \pm 3.3^{\mathrm{ab}}$ & $36.6 \pm 3.4^{\mathrm{abc}}$ \\
\hline \multirow{6}{*}{$\begin{array}{l}\text { Hemoglobin } \\
(\mathrm{g} / \mathrm{dL})\end{array}$} & 0 & $9.8 \pm 0.3^{\mathrm{a}}$ & $10.1 \pm 0.6^{\mathrm{a}}$ & $10.1 \pm 0.7^{\mathrm{a}}$ \\
\hline & 0.5 & $12.8 \pm 0.8^{\mathrm{ab}}$ & $14.8 \pm 0.4^{\mathrm{ab}}$ & $11.1 \pm 3.0^{\mathrm{a}}$ \\
\hline & 1 & $14.5 \pm 2.3^{b}$ & $17.5 \pm 4.1^{\mathrm{b}}$ & $15.8 \pm 0.6^{\mathrm{b}}$ \\
\hline & 3 & $14.3 \pm 2.3^{\mathrm{b}}$ & $14.9 \pm 3.4^{\mathrm{ab}}$ & $14.5 \pm 1.3^{\mathrm{b}}$ \\
\hline & 6 & $11.0 \pm 1.3^{\mathrm{ab}}$ & $13.0 \pm 1.3^{\mathrm{ab}}$ & $14.4 \pm 0.9^{b}$ \\
\hline & 24 & $12.4 \pm 0.7^{\mathrm{ab}}$ & $10.6 \pm 3.9^{\mathrm{a}}$ & $14.7 \pm 0.1^{\mathrm{b}}$ \\
\hline \multirow{6}{*}{$\begin{array}{l}\text { Red blood cell } \\
\left(\times 10^{6} \text { cell } / \mu \ell\right)\end{array}$} & 0 & $2.7 \pm 0.7^{\mathrm{a}}$ & $2.8 \pm 0.5^{\mathrm{a}}$ & $2.6 \pm 0.5^{\mathrm{ab}}$ \\
\hline & 0.5 & $3.6 \pm 0.1^{\mathrm{ab}}$ & $4.3 \pm 0.3^{\mathrm{b}}$ & $2.2 \pm 0.6^{\mathrm{a}}$ \\
\hline & 1 & $5.9 \pm 1.0^{c}$ & $5.1 \pm 2.9^{c}$ & $5.9 \pm 1.4^{\mathrm{c}}$ \\
\hline & 3 & $3.3 \pm 0.4^{\mathrm{ab}}$ & $3.8 \pm 0.9^{b}$ & $4.2 \pm 0.6^{\mathrm{abc}}$ \\
\hline & 6 & $2.3 \pm 0.6^{\mathrm{a}}$ & $4.0 \pm 1.3^{b}$ & $5.7 \pm 1.5^{\mathrm{c}}$ \\
\hline & 24 & $4.5 \pm 1.6^{\mathrm{bc}}$ & $4.4 \pm 0.7^{\mathrm{b}}$ & $4.5 \pm 1.3^{\mathrm{bc}}$ \\
\hline \multirow{6}{*}{$\begin{array}{c}\mathrm{Na}^{+} \\
(\mathrm{mEq} / \mathrm{L})\end{array}$} & 0 & $163.5 \pm 2.1^{\mathrm{ab}}$ & $162.5 \pm 3.5^{\mathrm{a}}$ & $166.0 \pm 5.7^{\mathrm{ab}}$ \\
\hline & 0.5 & $171.7 \pm 3.5^{\mathrm{c}}$ & $173.3 \pm 4.9^{\mathrm{ab}}$ & $170.0 \pm 5.3^{\mathrm{bc}}$ \\
\hline & 1 & $168.0 \pm 4.6^{\mathrm{bc}}$ & $168.7 \pm 3.8^{\mathrm{ab}}$ & $171.0 \pm 6.2^{\mathrm{bc}}$ \\
\hline & 3 & $166.3 \pm 2.5^{\mathrm{abc}}$ & $165.3 \pm 4.6^{\mathrm{ab}}$ & $166.7 \pm 4.9^{\mathrm{ab}}$ \\
\hline & 6 & $161.0 \pm 2.0^{\mathrm{a}}$ & $169.3 \pm 2.9^{\mathrm{ab}}$ & $164.0 \pm 3.6^{\mathrm{a}}$ \\
\hline & 24 & $166.0 \pm 2.6^{\mathrm{abc}}$ & $166.3 \pm 3.5^{b}$ & $168.3 \pm 2.3^{b}$ \\
\hline \multirow{6}{*}{$\begin{array}{c}\mathrm{K}^{+} \\
(\mathrm{mEq} / \mathrm{L})\end{array}$} & 0 & $3.6 \pm 0.2^{\mathrm{b}}$ & $3.7 \pm 0.4^{\mathrm{b}}$ & $3.9 \pm 0.2^{\mathrm{b}}$ \\
\hline & 0.5 & $3.3 \pm 0.3^{\mathrm{ab}}$ & $4.2 \pm 1.4^{\mathrm{bc}}$ & $4.1 \pm 1.3^{\mathrm{bc}}$ \\
\hline & 1 & $3.3 \pm 0.2^{\mathrm{ab}}$ & $3.1 \pm 1.0^{\mathrm{a}}$ & $4.0 \pm 1.4^{\mathrm{bc}}$ \\
\hline & 3 & $3.2 \pm 0.1^{\mathrm{ab}}$ & $2.9 \pm 0.2^{\mathrm{a}}$ & $2.9 \pm 0.2^{\mathrm{a}}$ \\
\hline & 6 & $3.1 \pm 0.4^{\mathrm{ab}}$ & $3.1 \pm 0.3^{\mathrm{a}}$ & $3.1 \pm 0.3^{\mathrm{a}}$ \\
\hline & 24 & $3.0 \pm 0.1^{\mathrm{a}}$ & $3.2 \pm 0.4^{\mathrm{a}}$ & $3.3 \pm 0.4^{\mathrm{a}}$ \\
\hline \multirow{6}{*}{$\begin{array}{c}\mathrm{Cl}^{-} \\
(\mathrm{mEq} / \mathrm{L})\end{array}$} & 0 & $135.5 \pm 0.7^{\mathrm{a}}$ & $137.5 \pm 3.5^{\mathrm{a}}$ & $139.0 \pm 4.2^{\mathrm{b}}$ \\
\hline & 0.5 & $141.0 \pm 2.0^{\mathrm{b}}$ & $145.0 \pm 3.5^{\mathrm{bc}}$ & $135.0 \pm 2.8^{\mathrm{a}}$ \\
\hline & 1 & $139.7 \pm 5.1^{\mathrm{ab}}$ & $139.3 \pm 2.3^{\mathrm{ab}}$ & $142.0 \pm 5.0^{c}$ \\
\hline & 3 & $138.3 \pm 1.2^{\mathrm{ab}}$ & $143.3 \pm 5.7^{b}$ & $137.7 \pm 6.0^{\mathrm{ab}}$ \\
\hline & 6 & $136.0 \pm 3.0^{\mathrm{ab}}$ & $144.3 \pm 3.5^{\mathrm{b}}$ & $137.3 \pm 3.1^{\mathrm{ab}}$ \\
\hline & 24 & $138.7 \pm 4.2^{\mathrm{ab}}$ & $137.7 \pm 2.5^{\mathrm{a}}$ & $140.0 \pm 1.0^{\mathrm{bc}}$ \\
\hline \multirow{6}{*}{$\begin{array}{l}\text { Aspartate aminotransferase } \\
\qquad(\mathrm{IU} / \mathrm{L})\end{array}$} & 0 & $5.5 \pm 0.7^{\mathrm{ab}}$ & $5.1 \pm 0.1^{\mathrm{ab}}$ & $5.4 \pm 0.9^{\mathrm{ab}}$ \\
\hline & 0.5 & $4.0 \pm 2.8^{\mathrm{ab}}$ & $3.3 \pm 2.1^{\mathrm{a}}$ & $3.3 \pm 1.5^{\mathrm{ab}}$ \\
\hline & 1 & $9.0 \pm 5.7^{\mathrm{abc}}$ & $8.0 \pm 1.4^{\mathrm{b}}$ & $4.7 \pm 3.1^{\mathrm{ab}}$ \\
\hline & 3 & $15.5 \pm 2.1^{\mathrm{c}}$ & $2.0 \pm 1.4^{\mathrm{a}}$ & $4.0 \pm 2.6^{\mathrm{ab}}$ \\
\hline & 6 & $11.5 \pm 4.9^{\mathrm{bc}}$ & $1.5 \pm 0.7^{\mathrm{a}}$ & $2.5 \pm 2.1^{\mathrm{a}}$ \\
\hline & 24 & $2.3 \pm 0.6^{\mathrm{a}}$ & $4.3 \pm 2.3^{\mathrm{ab}}$ & $6.0 \pm 3.6^{\mathrm{ab}}$ \\
\hline \multirow{6}{*}{$\begin{array}{l}\text { Alanine aminotransferase } \\
\qquad(\mathrm{IU} / \mathrm{L})\end{array}$} & 0 & $2.0 \pm 0.0^{\mathrm{ab}}$ & $2.2 \pm 0.2^{\mathrm{ab}}$ & $1.5 \pm 0.6^{\mathrm{a}}$ \\
\hline & 0.5 & $1.7 \pm 1.2^{\mathrm{a}}$ & $1.7 \pm 1.2^{\mathrm{a}}$ & $1.3 \pm 0.6^{\mathrm{a}}$ \\
\hline & 1 & $2.5 \pm 0.7^{\mathrm{ab}}$ & $2.5 \pm 0 .^{\mathrm{ab}}$ & $2.3 \pm 1.5^{\mathrm{ab}}$ \\
\hline & 3 & $1.7 \pm 1.2^{\mathrm{a}}$ & $1.3 \pm 0.6^{\mathrm{a}}$ & $2.7 \pm 1.2^{\mathrm{ab}}$ \\
\hline & 6 & $1.7 \pm 0.2^{\mathrm{a}}$ & $1.3 \pm 0.6^{\mathrm{a}}$ & $2.0 \pm 1.4^{\mathrm{ab}}$ \\
\hline & 24 & $1.3 \pm 0.6^{\mathrm{a}}$ & $2.0 \pm 0.0^{\mathrm{ab}}$ & $2.7 \pm 1.5^{\mathrm{ab}}$ \\
\hline
\end{tabular}

*Control group was measured according to extracted time intervals of experimental group without anesthesia. The values are mean \pm SD $(n=10)$ of triplicate experiments. Means within each column in item followed by the alphabetic letter are not significantly different $(\mathrm{P}>0.05)$.

of previous research show that the increasing of plasma cortisol level was faster than the increasing of glucose concentrations $[1,13,14,18]$. However, our results showed that cortisol and glucose level increased at the same time.

One of the more traditional stress indicators has been blood lactic acid [19]. If experimental animal was added to chronic stress, then result of lactic acid concentration is high [20]. The accumulation of lactic acid in muscle or blood (hyperlacticemia) is now well accepted as an indicator of anaerobic metabolism due to fright or severe exertion [21]. However, the view that lactic acidosis is the ultimate cause of death that sometimes occurs after severe exercise has been challenged [22]. As mentioned previous study, the lactic acid level was not restored 
to normal after 24 hours, which suggested that stress due to transport cannot be relieved even after a 24 hours period [23]. Our research was measured lactic acid concentrations from 0.5 hour post anesthesia to 24 hours post anesthesia. For analyze correctly the change of lactic acid concentration, we have to determine measurement time from 0.5 hour post anesthesia to 48 hours post anesthesia. However, lactic acid concentrations of anesthetic groups in our results didn't show significant difference.

Concentrations of $\mathrm{Ht}, \mathrm{Hb}, \mathrm{RBC}, \mathrm{Na}^{+}, \mathrm{Cl}-\mathrm{K}^{+}$, AST and ALT were shown in Table 3. In all experimental groups, concentrations of Ht after anesthesia were higher than concentrations of those before anesthesia $(P<0.05$, Table 3). Concentrations of $\mathrm{Ht}$ in control and lidocaine- $\mathrm{HCl}$ anesthetic group were increase at 1 hour post anesthesia, and those in MS-222 anesthetic group were increase at 0.5 hour post anesthesia $(P<0.05)$. At 24 hours post anesthesia, Ht concentration of lidocaine$\mathrm{HCl}$ anesthetic group was highest than those of control and MS-222 anesthetic group. In all experimental groups, the trends of $\mathrm{Hb}$ and $\mathrm{RBC}$ were similar to those of $\mathrm{Ht}$, and values of $\mathrm{Hb}$ and $\mathrm{RBC}$ were highest at 1 hour post anesthesia. At 24 hours post anesthesia, $\mathrm{Hb}$ concentration of control group was lowest than those of MS-222 and lidocaine$\mathrm{HCl}$ anesthetic group, while $\mathrm{RBC}$ concentrations group showed no significant differences between control group and experimental group.

$\mathrm{Na}^{+}, \mathrm{Cl}^{-}$, and $\mathrm{K}^{+}$concentrations of lidocaine- $\mathrm{HCl}$ anesthetic group showed no significant differences during experimental period $(P>0.05$, Table 3). In MS-222 anesthetic group, $\mathrm{Na}^{+}$concentration showed significant differences $(P<0.05)$, whereas $\mathrm{Cl}^{-}$and $\mathrm{K}^{+}$concentrations didn't show significant differences $(P>0.05)$. In control group, $\mathrm{Na}^{+}$ and $\mathrm{K}^{+}$concentration showed significant differences $(P<0.05)$, whereas $\mathrm{Cl}^{-}$concentrations didn't show significant differences $(P>0.05)$. While experimental period, $\mathrm{Na}^{+}, \mathrm{Cl}^{-}$, and $\mathrm{K}^{+}$concentrations didn't show significant differences between control group and experimental groups. The trends of AST concentrations in all experimental groups were similar to those of $\mathrm{Na}^{+}$concentrations in all experimental groups. In control and MS-222 anesthetic group, AST concentration showed significant differences $(P<0.05)$, whereas AST concentrations in lidocaine- $\mathrm{HCl}$ anesthetic group didn't show significant differences $(P>0.05)$. ALT concentrations of all experimental groups didn't show significant difference between control group and experimental groups $(P>0.05)$.

In this study, greenling was shown to be sensitive to hematological responses of MS-222 and lidocaine- $\mathrm{HCl}$ by investigation of hematocrit (Ht), hemoglobin ( $\mathrm{Hb}$ ), red blood cell (RBC), osmolality, $\mathrm{Na}^{+}, \mathrm{Cl}^{-}, \mathrm{K}^{+}$, aspartate aminotransferase (AST) and alanine aminotransferase (ALT). Similar researches were reported for black rockfish, olive flounder, Paralichthys olivaceus and sweetfish, Plecoglossus altivelis [6,12,23]. Hematocrit levels are often elevated during stress to increase the oxygen supply to the major organs in response to the higher metabolic demand [24]. Previous study reported that hematocrit was increased by handling and confi nement stress in the triploid rainbow trout, Oncorhynchus mykiss and the brook trout, Salvelinus fontinalis [25]. In the air-breathing fish Megalops cyprinoides, hematocrit was increased by strenuous exercise [26].

Previous study reported that hematocrit and hemoglobin levels did not increase during confinement; it can be assumed that the fish did not need to increase their oxygen carrying capacity [24]. However, results in this study showed that hematocrit and hemoglobin concentrations of all experimental groups were increased until 1 hour post anesthesia and decreased after 3 hours post anesthesia. In this study, it can be assumed that the fish did need to increase the available oxygen. The reduction in hemoglobin levels may be the result of increased permeability of the gills to water, resulting in hemodilution and a net loss of ions [23]. Some metabolic levels $\left(\mathrm{Na}^{+}, \mathrm{Cl}, \mathrm{K}^{+}\right.$, AST and ALT) recovered within 24 hours post anesthesia, but a longer time would be required for normal metabolism to take place after fish have experienced stress. According to the report by previous study [27], complete physiological recovery from the stresses studied would take as long as 2 weeks. The results may vary depending on the stress and the physical status of the fish, but physiological recovery may take a large amount of time overall.

In previous study, anesthesia using lidocaine- $\mathrm{HCl}$ and $\mathrm{MS}-222$ proved to be an effective method for the transport of the greenling as sedation [3]. In this study, greenling was shown to be sensitive to physiological and hematological responses of MS-222 and lidocaine$\mathrm{HCl}$. Therefore, this study demonstrated that the MS-222 and lidocaine$\mathrm{HCl}$ have exceptional reduction effect of stress in greenling. Future investigations in greenling should focus on comparative physiological reactions and hematological characteristics induced by other fish anesthetics including clove oil.

\section{Acknowledgements}

This research was funded through project 2010-0021293 of the National Research Foundation of Korea, Korea. Comments from anonymous reviewers greatly improved the quality of this manuscript. All experiments in this study complied with the current laws of Korea (the Law Regarding Experimental Animals, No. 9932).

\section{References}

1. Park MO, Im S-Y, Seol D-W, Park I-S (2009a) Efficacy and physiological responses of rock bream (Oplegnathus fasciatus) to anesthetization with clove oil. Aquaculture 287: $427-430$

2. Summerfelt RC, Smith LS (1990) Anesthesia, surgery, and related techniques. In: Methods for Fish Biology, American Fisheries Society, Bethesda, MD, USA, pp 213272 .

3. Park I-S, Jo JH, Lee SJ, Kim YA, Kim KE, Hur JW, Yoo JS, Song YC (2003) Anaesthetic effect of lidocaine hydrochloride-sodium bicarbonate and MS-222 on the greenling (Hexagrammos otakii). J Kor Fish Soc 36: 449-453 (in Korean with an English abstract).

4. Hasler AD, Meyer PK (1942) Respiratory responses of normal and castrated goldfish to teleost and mammalian hormones. J Exp Zool 91: 391-404.

5. Carrsco S, Sumano H, Navarro-Fierro R (1984) The use of lidocaine-sodium bicarbonate as anaesthetic in fish. Aquaculture 41: 395-398.

6. Hur JW, Park I-S, Kho KH, Chang YJ (2005) Changes of hematological characteristics of cultured sweetfish (Plecoglossus altivelis) by anaesthetic transport. Ocean Polar Res 27: 59-65.

7. Park I-S, Kim E-M, Woo SR, Oh S-Y, Kim DS, Hur JW (2006) Temperature-dependent index of mitotic interval $\left(\tau_{0}\right)$ in greenling, Hexagrammos otakii. Fish Sci 72: 719-722.

8. Woolsey J, Holcomb M, Ingermann RL (2004) Effect of temperature on clove oil anesthesia in steelhead fry. North Amer J Aquacult 66: 35-41.

9. Donaldson EM (1981) The pituitary-interrenal axis as an indicator of stress in fish. In Stress in Fish, Academic Press, London, UK, pp 11-47.

10. Raabo E, Terkildsen TC (1960) On the enzymatic determination of blood glucose Scand J Invest 12: 402-407. [Crossref]

11. Duncan DB (1955) Multiple-range and multiple $F$ tests. Biometrics 1: 1-42.

12. Kim JH, Hur JW, Park I-S, Kho KH, Chang YJ (2005) Effects of the different anesthetic doses of MS-222 and lidocaine-HCl on blood physiological responses in black rockfish, Sebastes schlegeli. J Aquacult 18: 236-244 (in Korean with an English abstract).

13. Park MO, Hur WJ, Im SY, Seol DS, Lee JH, Park I-S (2008) Anaesthetic efficacy and physiological responses to clove oil-anaesthetized kelp grouper, Epinephelus bruneus. Aquacult Res 39: 877-884. 
14. Park MO, Ji L, Gil HW, Kim DS, Park I-S (2009b) Physiological responses of darkbanded rockfish Sebastes inermis to anesthetization with clove oil. J Aquacult 22: 6367 (in Korean with an English abstract).

15. Schreck CB (1982) Stress and rearing of salmonids. Aquaculture 28: 241-249.

16. Massee KC, Rust MB, Hardy RW, Stickney RR (1995) The effectiveness of tricaine, quinaldine sulfate and metomidate as anesthetics for larval fish. Aquaculture 134: 351359.

17. Barton BA, Iwama GK (1991) Physiological changes in fish from stress in aquaculture with emphasis on the response and effects of corticosteroids. Annu Rev Fish Dis 1: $3-26$

18. Chang YJ, Hur JW (1999) Physiological responses of grey mullet (Mugil cephalus) and Nile tilapia (Oreochromis niloticus) by rapid changes in salinity of rearing water. $J$ Korean Fish Soc 32: 310-316 (in Korean with an English abstract).

19. Pickering AD, Pottinger TG (1989) Stress responses and diseases resistance in salmonid fish: effects of chronic elevation of plasma cortisol. Fish Physiol Biochem 7: 253-258. [Crossref]

20. Wedemeyer GA, Barton BA, McLeay DJ (1990) Stress and acclimation. In: Methods for Fish Biology, American Fisheries Society, Bechesda, MD, USA, pp: 451-489.
21. Turner JD, Wood CM, Clark D (1983) Lactate and proton dynamics in the rainbow trout (Salmo gairdneri). J Exp Biol 104: 247-268.

22. Wood CM, Turner JD, Graham MS (1983) Why do fish die after severe exercise? J Fish Biol 22: 189-201.

23. Hur JW, Park I-S, Chang YJ (2007) Physiological responses of the olive flounder, Paralichthys olivaceus, to a series stress during the transportation process. Ichthyol Res 54: 32-37.

24. Ruane NM, Wendelaar BSE, Balm PHM (1999) Differences between rainbow trout and brown trout in the regulation of the pituitary-interrenal axis and physiologica performance during confinement. Gen Comp Endocrinol 115: 210-219. [Crossref]

25. Tillmann JB, Biron M (2000) Acute stress response in triploid rainbow trout (Oncorhynchus mykiss) and brook trout (Salvelinus fontinalis). Aquaculture 184: 167176

26. Wells RMG, Baldwin J, Seymour RS, Baudinette RV, Christian K, Bennett MB (2003) Oxygen transport capacity in the air-breathing fish, Megalops cyprinoides compensations for strenuous exercise. Comp Biochem Physiol 134: 45-53. [Crossref]

27. Pickering AD, Pottinger TG, Christic P (1982) Recovery of the brown trout, Salmo trutta L., from acute handling stress: a time-course study. J Fish Biol 20: 229-244.

Copyright: $\mathbb{C} 2015$ Park IS. This is an open-access article distributed under the terms of the Creative Commons Attribution License, which permits unrestricted use, distribution, and reproduction in any medium, provided the original author and source are credited. 